\title{
Pembuatan Septic Tank Komunal Solusi Kesehatan Bagi Masyarakat Pesisir Desa Bokori Kecamatan Soropia
}

\author{
Titi Saparina L*, Leniarti Ali \\ Program Studi Kesehatan Masyarakat, Universitas Mandala Waluya
}

\begin{abstract}
ABSTRAK
Data yang diperoleh dari kantor Kecamatan Soropia bahwa Kepala Keluarga yang memiliki Jamban di Desa Bokori hanya berjumlah 38 KK dari total KK 85 KK yang artinya lebih dari $50 \%$ KK tidak memiliki jamban sehingga Masyarakat yang tinggal di kawasan pesisir tersebut membuang tinjanya langsung ke laut. Untuk meminimalisir dampak dari pembuangan tinja ke laut diperlukan solusi yang efektif, mudah diimplementasikan serta mudah untuk mengelola pembuangan tinja bagi masyarakat pesisir dan mengingat kondisi kawasan pesisir yang landai, berpasir dan sangat mudah terendam, diperlukan teknik khusus dalam membuat septic tank yakni penerapan Teknologi Tepat Gua berupa septic tank komunal. Permasalahan dalam kegiatan pengabdian masyarakat ini yaitu Masih rendahnya kesadaran dan pemahaman masyarakat tentang pentingnya buang air besar menggunakan jamban dan septic tank, masyarakat belum mengetahui manfaat penggunaan septic tank komunal sebagai salah satu solusi buang air besar secara sehat. Dan masyarakat belum mengetahui tata cara pembuatan Teknologi tepat guna berupa septic tank komunal. Adapun solusi yang dapat ditawarkan dalam kegiatan pengabdian masyarakat ini adalah meningkatkan Kesadaran serta pemahaman masyarakat tentang pentingnya buang air besar menggunakan jamban dan tangki septik, memberikan pemahaman kepada masyarakat tentang dampak buang air besar sembarangan dan mengetahui septik tank komunal dapat menjadi solusi untuk mengatasi buang air besar sembarangan di daerah pesisir serta melakukan Demostrasi Plot (Demplot) Pembuatan Septik Tank Komunal.

Kata Kunci : Daerah Pesisir, BAB Sembarang, Pengetahuan, Jamban dan Septik Tank Komunal
\end{abstract}

\section{Making Communal Septic Tanks, Health Solutions for Coastal Communities, Bokori Village, Soropia District}

\begin{abstract}
The data obtained from the Soropia sub-district office shows that the head of the family owns a latrine. In Bokori Village, there are only 38 of the total 85 HHs, which means that more than $50 \%$ of the HHs do not have latrines so that the people living in the coastal area throw their feces directly into the sea. To minimize the impact of discharging feces into the sea, a solution that is effective, easy to implement and easy to manage feces disposal for coastal communities is needed and considering the conditions of the sloping, sandy and very submerged coastal areas, special techniques are needed in making septic tanks, namely the application of appropriate cave technology. in the form of a communal septic tank. The problem in this community service activity is the low awareness and understanding of the community about the importance of defecating using latrines and septic tanks, the community does not yet know the benefits of using communal septic tanks as a solution to healthy defecation. The public does not yet know the procedure for making appropriate technology in the form of a communal septic tank. The solutions that can be offered in this community service activity are increasing public awareness and understanding of the importance of defecating using latrines and septic tanks, providing understanding to the community about the impact of open defecation and knowing that communal septic tanks can be a solution to overcome defecation carelessly in the coastal area and conducted a demonstration plot (demonstration plot) for the construction of a communal tank septic.
\end{abstract}

Keywords: Coastal Areas, open defecation, Knowledge, Latrines and Communal Septic Tanks

Penulis Korespondensi :

Titi Saparina L

Program Studi Kesehatan Masyarakat Universitas Mandala Waluya Sulawesi Tenggara

E-mail : titisaparina.stikesmw@gmail.com

No.Hp : 082193390163 
PENDAHULUAN

Indonesia sebagai negara

berkembang saat ini mempunyai permasalahan di bidang sanitasi dan perilaku hidup bersih dan sehat. Masalah sanitasi ini dapat menimbulkan kerusakan pada lingkungan secara fisik maupun mental sosial masyarakat. Salah satu cara sanitasi yakni dengan menjaga kebersihan dari segala unsur yang mempengaruhi kelestarian lingkungan dan yang paling tepat memungkinkan menghindarkan timbulnya gangguan dan penyakit (Bappenas RI, 2011).

Perilaku buang air besar sembarangan merupakan salah satu faktor yang berkontribusi besar terhadap kejadian kematian anak di Indonesia. Berdasarkan catatan UNICEF tahun 2015 sebanyak 1,7 miliar anak berusia balita di dunia menderita kasus diare. Sekitar 300.000 meninggal setiap tahun atau lebih dari 800 per hari menderita penyakit diare yang diakibatkan air, sanitasi dan kebersihan yang buruk. Selain penyakit, perilaku buang air besar sembarangan juga memperbesar risiko yang menghambat pertumbuhan fisik anak-anak (Setyanti, 2015)

Menurut laporan Join Monitoring Program (JMP) WHO tahun 2017 menyebutkan jumlah penduduk buang air besar sembarangan di Indonesia sebanyak 31 juta jiwa (Laporan Joint Monitoring Program, 2017)

Masyarakat pesisir sebagian besar merupakan masyarakat nelayan memiliki karakteristik yang berbeda dengan masyarakat lainnya. Perbedaan ini dikarenakan keterkaitannya yang erat dengan karakterstik ekonomi wilayah pesisir, latar belakang budaya dan ketersediaan sarana dan prasarana penunjang. Permasalahan yang sering timbul di wilayah pesisir yakni rendahnya tingkat kesejahteraan masyarakat dan rendahnya kualitas lingkungan. Tingkat kesejahteraan masyarakat yang rendah tercermin dari kualitas lingkungan dan rumah yang mereka tingggal. Lingkungan yang buruk dapat diidentifikasi dengan melihat aspek aspek yang berpengaruh pada kualitas hunian tersebut seperti jaringan air bersih, drainase, persampahan, fasilitas serta jamban.

Di Desa Bokori Kecamatan Soropia Kabupaten Konawe masih banyak masyarakat yang buang air besar sembarangan, terutama masyarakat yang tinggal di daerah pesisir. Data yang diperoleh dari kantor Kecamatan Soropia Tahun 2019 bahwa Kepala Keluarga yang memiliki Jamban di Desa Bokori hanya berjumlah $38 \mathrm{KK}$ dari total KK $85 \mathrm{KK}$ yang artinya lebih dari 50\% KK tidak memiliki jamban sehingga Masyarakat yang tinggal di kawasan pesisir tersebut membuang tinjanya langsung ke laut. Sebagian dari mereka masih menjadikan rawa-rawa dan saluran drainase sebagai tempat Buang Air Besar dan sudah menjadi kebiasaan masyarakat yang memandang kawasan pesisir tersebut adalah septic tank raksasa sehingga tidak perlu repot mengeluarkan biaya untuk membangun sarana pembuangan tinja yang semestinya dan kenyataannya selama ini KK yang tidak memiliki jamban, memanfaatkan pesisir sebagai tempat Buang Air Besar (Laporan PBL 1 Desa Bokori Kecamatan Soropia, 2019). 
Masalah pembuangan tinja harus mendapat perhatian khusus karena merupakan satu bahan buangan yang banyak mendatangkan masalah dalam bidang kesehatan karena dapat menjadi media bibit penyakit, seperti: diare, typus, kolera, disentri, dan lain-lain. Selain itu, pembuangan tinja yang tidak saniter juga dapat menimbulkan pencemaran lingkungan pada sumber air, bau busuk serta berdampak pada estetika.

Untuk meminimalisir dampak dari pembuangan tinja ke laut diperlukan solusi yang efektif, mudah diimplementasikan serta mudah untuk mengelola pembuangan tinja bagi masyarakat pesisir dan mengingat kondisi kawasan pesisir yang landai, berpasir dan sangat mudah terendam, diperlukan teknik khusus dalam membuat septic tank. Karena, dengan kondisi yang mudah terendam, septic yang dibuat harus memperhatikan jarak dengan sumber air. Jangan sampai kotoran mengkontaminasi air yang akan digunakan sehari-hari. Teknologi tepat guna berupa Septik tank komunal adalah rancangan sarana pembuangan tinja yang dapat menjadi solusi bagi masyarakat pesisir daerah pasang surut air laut dalam membuang tinja yang aman.

\section{METODE}

Metode yang digunakan oleh tim pengabdian dalam kegiatan Pengabdian Kepada Masyarakat ini pada dasarnya merupakaan metode adopsi yang sering digunakan untuk meningkatkan derajat kesehatan masyarakat yakni :

1. Meningkatkan kesadaran kepada masyarakat melalui kegiatan penyuluhan kesehatan tentang pentingnya buang air besar menggunakan jamban sehatt melalui septic tank komunal khususnya bagi masyarakat pesisir.

2. Memberikan Pendidikan Kesehatan Kepada Masyarakat khususnya masyarakat Desa Bokori tentang dampak buang air besar sembarangan dan mengetahui septik tank komunal dapat menjadi solusi untuk mengatasi buang air besar sembarangan di daerah pesisir.

3. Melakukan Demostrasi Plot (Demplot) Pembuatan Septik Tank Komunal. Metode Demplot dilakukan dengan pertimbangan mitra dapat terlibat langsung dalam kegiatan pembuatan septic tank komunal.

Adapun tahapan kegiatan yang akan dilakukan adalah sebagai berikut :

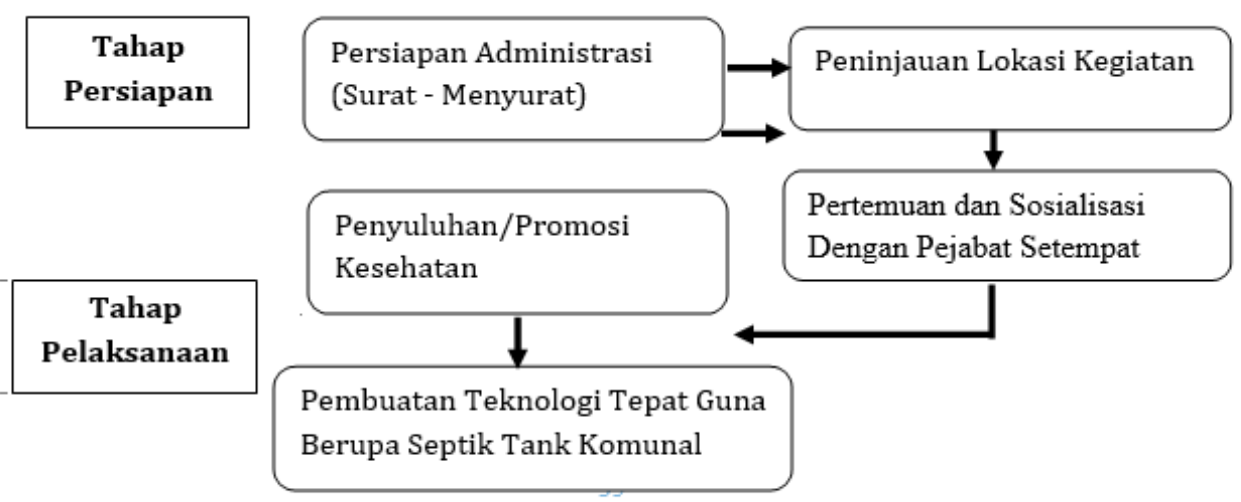

Gambar 1. Tahapan Kegiatan 


\section{HASIL DAN PEMBAHASAN}

Kegiatan Pengabdian Masyarakat ini dilaksanakan di Desa Bokori Kecamatan Soropia. Tim Pengabdian Masyarakat ini terdiri dari Dosen dan Mahasiswa. Adapun hasil dari kegiatan pengabdian masyarakat ini berupa
Septik Tank Komunal yang dapat digunakan oleh masyarakat setempat khususnya yang berada pada daerah pesisir. Adapun model/gambar septic tank yang dibuat oleh tim pengabdian kepada masyarakat yakni sebagai berikut:

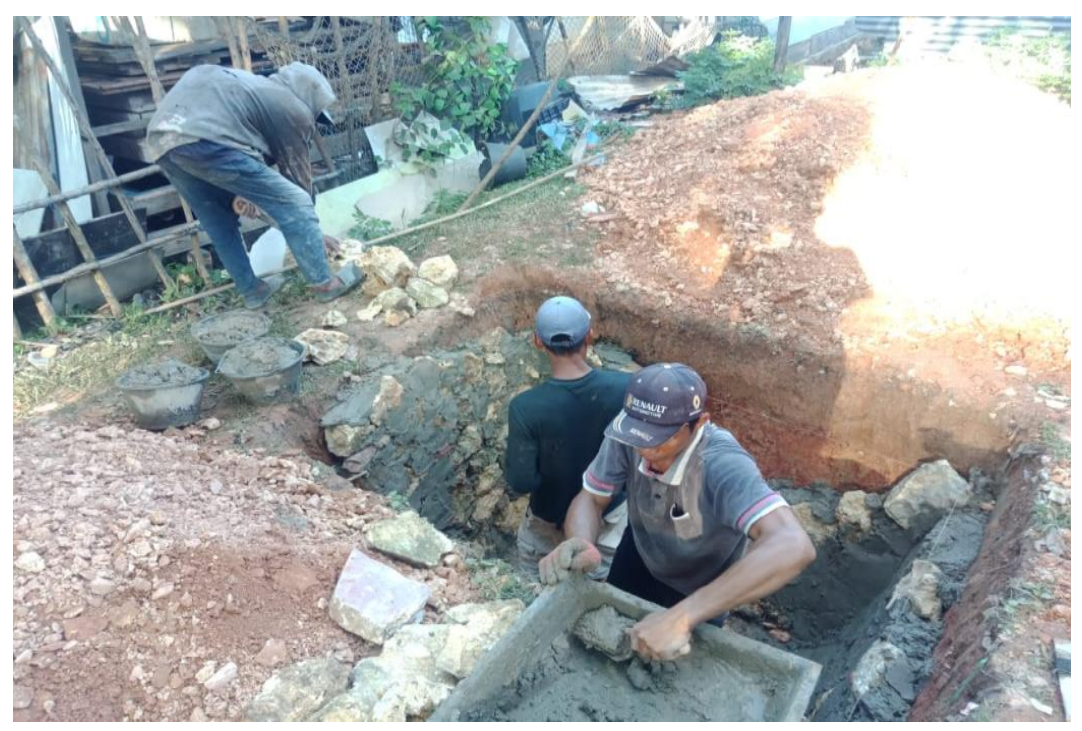

Gambar 2. Pembutan Septik Tank Komunal

Berdasarkan SNI: 03-2398-2002, mengenai perencanaan septic-tank dengan sistem resapan, diatur standar prosedur pembangunan septic-tank, termasuk ukuran dan batasan kebutuhan minimum fasilitas septic tank. Selain itu, juga persyaratan jarak minimum septic-tank terhadap bangunan. Berdasarkan standar itu, bangunan septic tank harus kuat, tahan terhadap asam, dan kedap air artinya, yang dibuat yakni berukuran $2 \times 1$. tidak boleh ada rembesan yang keluar dari tangki. Kemudian, bahan yang diizinkan untuk membuat penutup dan pipa penyalur air limbah adalah batu kali, bata merah, batako, beton bertulang, beton tanpa tulang, PVC, keramik, pelat besi, plastik, dan besi dan adapun ukuran septic tank Yang di buat oleh tim pengabdian masyarakat berukuran $\mathrm{m}$ 


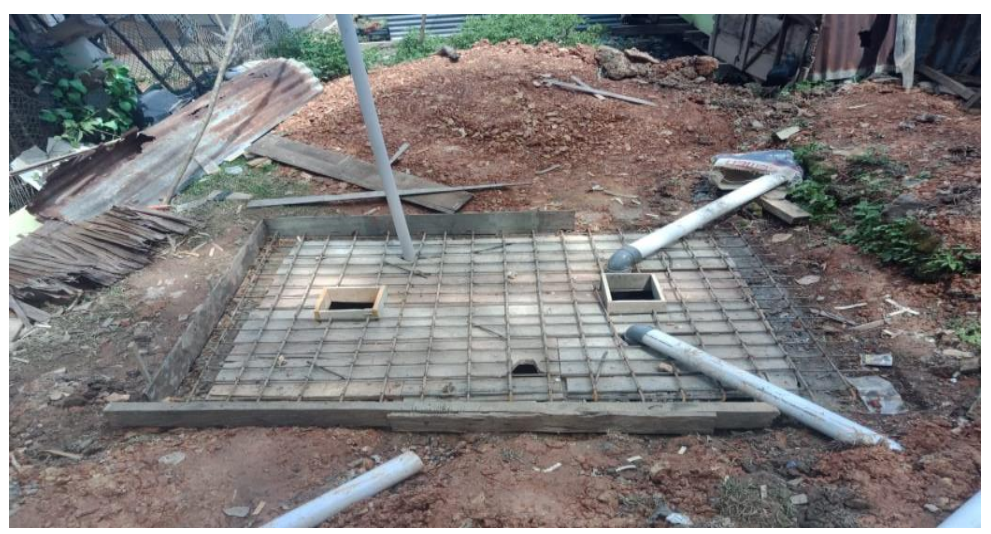

Gambar 3. Kontruksi Septik Tank Komunal

Pembangunan septic tank komunal yang dilakukan di Desa Bokori Kecamatan Soropia sebenarnya belum sesuai dengan konsep septic tank komunal, dimana 1 septic tank diperuntukkan bagi 4-5 rumah tangga. Hal tersebut terjadi karena pada saat pemilihan lokasi untuk pembangunan septic tank dari Tim Pengabdian Masyarakat mengalami kendala dan kesulitan dalam menentukan lokasi yang sesuai, mengingat waktu pelaksanaan yang singkat, sehingga perlu dipertimbangkan untuk merencanakan kegiatan sesuai waktu yang dibutuhkan. Dengan dibangunnya septic tank komunal diharapkan masyarakat desa tidak lagi buang air besar di sembarang tempat yang tidak mempunyai saluran buangan air limbah yang dapat menyebarkan penyakit. Penyebab penyakit infeksi yang berhubungan dengan sanitasi buruk adalah bakteri, virus, parasit, dan jamur.

$$
\text { Stop Buang Air Besar }
$$

Sembarangan (STOP BABS) yang merupakan salah satu kegiatan Sanitasi Total Berbasis Masyarakat (STBM) adalah suatu program pemberdayaan masyarakat dalam bidang sanitasi dimana kegiatannya diarahkan pada perubahan perilaku dari Buang Air Besar Sembarangan menuju pada suatu tempat tertentu (jamban/kakus) sekalipun hanya dalam bentuk yang paling sederhana berupa lubang atau galian yang diberi tempat jongkokan yang dapat mencegah terhadap bau yang tidak sedap, pencemaran terhadap sumber-sumber air bersih, serta keterjangkauan lalat yang dapat menyebabkan penyakit berbasis lingkungan misalnya saja penyakit diare. Sanitasi Total Berbasis Masyarakat (STBM) adalah pendekatan untuk merubah perilaku higiene dan sanitasi melalui pemberdayaan masyarakat dengan metode pemicuan. Ada 5 pilar dalam STBM, yaitu:

1. Stop buang air besar sembarangan.

2. Cuci tangan pakai sabun.

3. Pengelolaan air minum/makanan rumah tangga.

4. Pengelolaan sampah rumah tangga.

5. Pengelolaan limbah cair rumah tangga.

Program nasional STBM dikhususkan untuk skala rumah tangga, sehingga program ini adalah program yang berbasis masyarakat, dan tanpa 
memberikan subsidi sama sekali bagi rumah tangga. Pembuatan septic tank komunal yang dilakukan oleh Tim Pengabdian Masyarakat merupakan stimulasi kepada masyarakat, sehingga tidak bertentangan dengan prinsip STBM yang berbasis masyarakat. Stimulasi dengan melibatkan masyarakat, aparat desa, serta petugas puskesmas. Jumlah penduduk yang akan menggunakan WC komunal akan menentukan besarnya volume tangki/lubang septik. Semakin besar jumlah penduduk, semakin besar pula lahan yang harus disediakan dalam merancang lubang septik. Kegiatan pengabdian masyarakat di Desa Bokori Kecamatan Soropia merupakan kegiatan yang dilakukan oleh Tim Pengabdian Masyarakat yang difokuskan pada perilaku masyarakat yang membuang air besar sembarangan dengan pembangunan septic tank komunal yang sesuai dengan standar nasional Indonesia (SNI) khusus didaerah pesisir dan untuk kegiatan penyuluhan mengenai perilaku buang air besar tidak sembarangan di lakukan oleh Dosen Program Studi S1 Ilmu Kesehatan Masyarakat terkait bahaya atau dampak buang air besar sembarang tempat yang dapat mengakibatkan penyebaran penyakit.

\section{KESIMPULAN}

Berdasarkan uraian hasil kegiatan Pengabdian Kepada Masyarakat, maka dapat ditarik kesimpulan sebagai berikut :

\section{DAFTAR PUSTAKA}

Bappenas RI. (2011). Kebijakan Nasional Penyehatan Air Minum dan Penyehatan
1. Peningkatan Kesadaran Masyarakat Tentang BAB Pada Tempatnya berdampak baik bagi pengetahuan Masyarakaat Desa Bokori dengan dilakukannya penyuluhan kesehatan.

2. Peningkatan Pengetahuan Masyarakat mengenai Dampak BAB Disembarang tempat melalui Pendidikan Kesehatan Bagi Masyarakat Desa Bokori.

3. Pembuatan Septik Tank Komunal Bagi Masyarakat Pesisir melalui kegiataan Demonstrasi Plot dan sebagai upaya solusi Kesehatan bagi Masyarakat Daerah Pesisir Khususnya Desa Bokori.

\section{UCAPAN TERIMAKASIH}

Penulis menyampaikan ucapan terima kasih kepada Lembaga Penelitian dan Pengabdian Masyarakat Universitas Mandala Waluya Maupun Yayasan Mandala Waluya yang telah memberikan kesempatan kepada kami untuk melaksanakan tridharma Perguruaan Tinggi utamanya dalam Pengabdian Kepada Masyarakat. Tak lupa pula kami ucapkan terimakasih pula kepada pihak terkait yang telah banyak membantu dan memberikan dukungan kepada Kami dalam pelaksaanaan kegiatan Pengabdiaan Kepada Masyarakat ini mulai dari Kepala Desa Bokori utamanya terkait kesediaaan lokasi pengabdian, masyarakat Desa Bokori dan mahasiswa tugas akhir.

Lingkungan Berbasis Masyarakat. Bappenas.

Laporan Joint Monitoring Program. (2017). 
Indonesia Darurat Buang Air Besar Sembarangan (BABS). https://www.change.org/. 28 Februari 2018 (8.17 PM)

Laporan PBL 1 Desa Bokori Kecamatan Soropia. (2019).

Setyanti, C. A. (2015). Berita Kesehatan (51 Juta Orang Indonesia Buang Air Besar Sembarangan). 